\title{
Anal Canal Carcinoma
}

National Cancer Institute

\section{Source}

National Cancer Institute. Anal Canal Carcinoma. NCI Thesaurus. Code C7489.

A squamous cell carcinoma or less frequently an adenocarcinoma, often associated with human papillomavirus (HPV) infection. Homosexual men are at particular risk. The most important prognostic factors are tumor stage and nodal status. 